\title{
Clinical case: OnLine intervention proposal for a patient with symptoms of depression and anxiety.
}

\author{
Caso clínico: elaboración de una propuesta de intervención OnLine para una paciente con rasgos \\ de depresión y ansiedad. \\ Alinne C. Vargas-Olmedo ${ }^{a}$, María, A. Carrizales-Tabares ${ }^{b}$, Andrea C. Azpeitia-Ayala $^{c}$ \\ 'Yenissa Y. Galicia-Salazar ${ }^{d}$, Christian S. Gonzalez-Camarillo ${ }^{e}$.
}

\begin{abstract}
:
Anxiety and depression are some of the mental health problems that have increased, mainly due to the health contingency caused by the COVID-19 pandemic. Therefore, the objective of the present work was to describe the process to be followed for the development of an OnLine intervention proposal, based on the Cognitive Behavioral Model and oriented to a 21-year-old female patient who manifests symptoms of depression and anxiety. Data collection strategies based on the Problem Solving Model and the functional behavioral analysis were used to formulate the case and integrate the Clinical Map of Pathogenesis and the Map of Scope of Goals. In addition, the patient was evaluated with a battery of psychometric instruments suitable for the Mexican population, such as the State-Trait Anxiety Inventory, Hamilton Anxiety Scale, Manifest Anxiety Scale in Adults-C, Hamilton Evaluation Scale for Depression, and the Beck-II Depression Inventory. Derived from the case formulation and the results obtained in the psychometric evaluation, an intervention proposal was integrated that includes effective strategies to achieve the therapeutic objectives: 1. Psychoeducation, 2. Cognitive restructuring technique, 3. Training in breathing techniques, 4. Relaxation technique training, 5. Sleep hygiene training, and 6. Mindfulness techniques. It can be concluded that the careful planning and development of the intervention proposal is a crucial piece in clinical work with patients with emotional disturbances.
\end{abstract}

\section{Keywords:}

Intervention, Cognitive-Behavioural, COVID-19, Telepsychology, Study case

\begin{abstract}
Resumen:
La ansiedad y la depresión son algunos de los problemas de salud mental que han aumentado, especialmente como consecuencia de la contingencia sanitaria por la pandemia derivada del COVID-19. Por lo tanto el objetivo del presente trabajo fue describir el proceso que se debe seguir para el desarrollo de una propuesta de intervención OnLine, basada en el Modelo Cognitivo Conductual y orientada a una paciente del sexo femenino de 21 años de edad, quien manifiesta síntomas de depresión y ansiedad. Se emplearon estrategias de recolección de información sustentadas en el modelo de Solución de Problemas y en el análisis funcional de la conducta para la formulación del caso, cómo es la integración del Mapa Clínico de Patogénesis y el Mapa de Alcance de Metas. Además, la paciente fue evaluada con una batería de instrumentos psicométricos adecuados para población mexicana como son el Inventario de Ansiedad Rasgo-Estado, Escala de Ansiedad de Hamilton, Escala de Ansiedad Manifiesta en Adultos-C, Escala de Evaluación para la Depresión de Hamilton y el Inventario de Depresión de Beck-II. Derivado de la formulación del caso y de los resultados obtenidos en la evaluación psicométrica se integró una propuesta de intervención que incluye estrategias efectivas para el logro de los objetivos terapéuticos: 1. Psicoeducación, 2. Técnica de reestructuración cognitiva, 3. Entrenamiento en técnicas de respiración, 4. Entrenamiento en técnica de relajación, 5. Entrenamiento en higiene del sueño y 6. Técnicas de atención plena. Se puede concluir que la planeación y desarrollo cuidadoso de la propuesta de intervención es una pieza clave en el trabajo clínico con pacientes que presentan alteraciones emocionales.
\end{abstract}

\section{Palabras Clave:}

Intervención, Cognitivo-conductual, COVID-19, Telepsicología, Estudio de caso.

\footnotetext{
a Corresponding author, Universidad La Salle Victoria, https://orcid.org/0000-0002-6228
alinnevargas.1529@ulsavictoria.edu.mx
b Universidad La Salle Victoria, https://orcid.org/0000-0002-4799-5012, Email: angelicacarrizales1@gmail.com
c Universidad La Salle Victoria, https://orcid.org/0000-0002-3832-8242, Email: andrea.azpeitia.ayala@ @mail.com

Universidad La Salle Victoria, https://orcid.org/0000-0002-6846-1749, Email: yeni.salazar08@gmail.com

Universidad La Salle Victoria, https://orcid.org/0000-0002-5632-6232, Email: christiansgonzalezc@gmail.com
} 


\section{INTRODUCTION}

According to Kazdin (2019), the specific methodology used in the case studies is a fundamental tool for clinical work. The objective of a case study is to get to the essence of a problem, specifying and detailing its parts, delving into the factors of why it happens in that specific way (Soto \& Escribano, 2019; Stake, 2007).

According to the Mexican Council of Neuroscience (2018), mental health constitutes a concept with a certain complexity of understanding due to the multiple factors that can intervene to determine its existence, such as social, environmental, psychological, and even biological.

Over the years, a decrease in mental health has been noted in the Mexican population from an increase in depressive and anxiety syndromes, schizophrenia, addictions, etc. (Consejo Mexicano de Neurosciencia, 2018).

The development of mental disorders is diverse and includes biological and psychosocial factors that serve as a reference to confirm a diagnosis of depression or anxiety (Espinosa,

Orozco, \& Ybarra, 2015).

According to the 2019 data of the National Institute of Statistics and Geography [INEGI] indicates that suicide is the second cause of death in people between 15 and 29 years. In addition, the 20 to 24 age group has the highest rate, with 9.3 suicides per 100,000 people.

Considering the events related to COVID-19, a decrease in the psychological well-being of people worldwide has been noted since compared to the times preceding the virus outbreak; the Weibo application registered an increase in the use of words that indicate symptoms of anxiety and depression ( $\mathrm{Li}$ et al., 2020; Vindegaard \& Eriksen, 2020).

Vindegaard and Eriksen (2020), in their study "COVID-19 pandemic and mental health consequences: Systematic review of the current evidence", showed through 43 studies that patients who suffered COVID-19 and were hospitalized showed symptoms of post-traumatic stress; on the other hand, there was an increase in symptoms of depression in people in quarantine and patients suffering from the virus, the latter group being the one with more pronounced symptoms, higher restrictions due to lockdown measures, a more significant reduction of social contacts and more significant perceived life changes were associated with higher mental health impairments (Benke et al. 2020). Another study found that patients with eating disorders or other pre-existing psychiatric disorders suffered a worsening in their symptoms, with anxiety being the symptom that worsened the most (Fernández-Aranda et al., 2020; Vindegaard \& Eriksen, 2020;).

Other studies report an increase in symptoms of depression and anxiety and features of obsessive-compulsive disorder in health personnel (Vidergaard \& Eriksen, 2020; Zhang, 2020) during the COVID-19 pandemic. And according to Argüero and collaborators (2020), the COVID-19 pandemic brings with it an increase in symptoms of stress, anxiety, and depression in the population at high to moderate levels. This requires more significant preparation in mental health professionals to get the best handling of these phenomena.

With this increase in the need for psychological care, it has been chosen to integrate technology into treatment as a connecting and therapeutic tool. Cognitive-behavioral therapy has adapted with the same effectiveness as in its face-to-face modality (Gaja, 2017). Interventions via the internet have turned out to be novel and innovative and obtain encouraging results.
However, not all countries have achieved robust research and development in the field (Li et al., 2020).

In Latin American countries, such as Mexico, the degree of research and technological development used in clinical psychology, still incipient and need better results (De la Rosa \& De la Rosa, 2020). Different organizations and health professionals have recognized cognitive-behavioral therapy as one of the best alternatives to treat anxiety and depression, even on top of pharmacological treatments (Gaja, 2017).

Another tool that cognitive-behavioral therapy offers is functional behavioral analysis, which is used mainly in the evaluation process and as a behavioral modification tool, and consists of analyzing the center of the patient's problem and its relationship with the context in which it occurs (Cooper, Heron, \& Heward, 2019).

Knaevelsrud and Maercker (2007) published a study where the effectiveness of cognitive-behavioral therapy applied virtually in patients with post-traumatic stress was measured. They were evaluated at the end of treatment and three months later, finding that the severity of post-traumatic stress had been significantly reduced and symptoms of anxiety and depression present in the patients. It was concluded by demonstrating the effectiveness of online therapy for post-traumatic stress disorder symptoms and symptoms of depression and anxiety. It was also shown that a solid therapeutic relationship could be created with the patient despite taking OnLine therapy.

In 2014, Wagner, Horn, and Maercker carried out an investigation where two groups of patients with depression received the same 8 -week program of cognitive-behavioral therapy, with the difference that one group would receive it in person and another OnLine. The study found no significant differences in the improvement of patients in both groups, indicating and confirming that face-to-face or virtual therapy has the same benefits.

On the other hand, Olthuis, Watt, Bailey, Hayden, and Stewart (2015) mention that Online cognitive-behavioral therapy (OCBT) is a tool to solve accessibility to face-to-face treatment therapists can provide help via phone, online, or by mail. They also conclude that OCBT is relatively efficient in improving anxiety and its symptoms.

In the same way, Flores, Cárdenas, Durán, and De la Rosa in 2014 also carried out a cognitive-behavioral intervention in OnLine mode in a population aged 19 to 48 years with depression, achieving effective results and well-being in patients.

\section{METHOD}

The objective of this work was to develop a proposal for a cognitive-behavioral intervention using the cognitivebehavioral model for a patient with anxiety and depression traits, to be treated online through four sessions of psychological assessment.

\section{PATIENT IDENTIFICATION}

M.L. is a 20-year-old woman, student of the Bachelor in Graphic Design. She currently lives with her 42-year-old mother; her father is 46 ; her sister is 15 years old, and her brother is nine years old.

\section{ANALYSIS OF THE REASON FOR CONSULTATION}

M.L. goes for a virtual consultation, commenting that she has been experiencing anxiety symptoms since the government 
established the quarantine due to the COVID-19 pandemic. She has been suffering from constant crying, cold sweat accompanied by tremors and nausea, and an increase in respiratory rate. She comments that this symptomatology was experienced between 1 and 2 times a week, of which they can occur approximately two times a day and randomly.

\section{HISTORY OF THE PROBLEM}

During her high school stage, the patient mentions that around the 5th semester, she went to psychological therapy to treat that she was in a relationship that she describes as "toxic" because it caused problems with her other social relationships. She points out that she was diagnosed with depression. However, she abandons psychotherapeutic treatment before finishing due she perceived herself as feeling better. Nevertheless, when she began confinement due to the pandemic, she noticed anxiety symptoms in herself. The last time she noticed the symptoms occurred when she felt overwhelmed by the pressure of taking care of her younger brother. Added to that, the fact that her mother reprimanded her when she got home from work caused her feelings of guilt. She says that after the scolding, she experienced shaking, cold sweat, nausea, and crying.

In addition to the above, during 2020, the patient was diagnosed with Polycystic Ovary Syndrome, for which she received hormonal treatment. Nevertheless, the patient stopped following the medical treatment at the time of the therapeutic evaluation.

\section{INSTRUMENTS FOR PSYCHOLOGICAL EVALUATION}

The instruments used for the psychological evaluation were the following:

- $\quad$ State-Trait Anxiety Inventory (IDARE).- The adaptation made by Castro in 2016 indicates that the reliability of the trait anxiety and state anxiety scales obtained a Cronbach's alpha of .83 and .90 in the Mexican population. This inventory consists of 40 items with a Likert scale divided into the two previously mentioned scales, made up of 20 items each.

Beck Depression Inventory-II (BDI-II). - Estrada, Delgado, Hernández, and González in 2015 reported that the Spanish adaptation of the Beck Depression Inventory carried out by Sanz, Navarro, and Vázquez in 2003 obtained a level of reliability 0.901 in the Mexican sample. This instrument includes 21 questions on a Likert scale that measure depression. The score ranges from 0 to a maximum of 63 points.

Hamilton Anxiety Scale. Instrument whose objective is to assess the severity of anxiety in a generalized way in patients who manifest anxiety or depression criteria and monitor the response to treatment. This test is of the hetero-administered type, which is composed of 14 items whose answers are presented on a Likert scale of five values. Internal reliability ranges from 0.79 to 0.86 (Hamilton, 1959; as cited in Esquivel, 2013).

Hamilton Depression Rating Scale. - Scale developed to be used in people previously diagnosed with depression, which contains 17 items. Ramos and Cordero (1986) carried out the validation into the Spanish version of this scale, with a Cronbach's alpha between 0.76 and 0.92. (as cited in Navarrete, 2014).
- $\quad$ Manifest Anxiety Scale in Adults-C (AMAS-C). - Made to detect and evaluate anxiety in university students. This test consists of 49 questions and presents four assessment scales for anxiety and a validity scale. The reliability of the test is 0.70 , and it has a $\mathrm{T}$ score of 30 to 77 points (Reynolds et al., 2007).

\section{RESULTS OF THE PSYCHOLOGICAL EVALUATION}

On the State-Trait Anxiety Instrument (IDARE), she obtained a score of 32, indicating a medium level in state anxiety; in trait anxiety her score was 46, interpreted as high (see Table 1). Also, within the Hamilton Anxiety Scale, she obtained 12 points in psychic anxiety and 7 in somatic (see Table 2).

The Manifest Anxiety Scale in Adults - C presents clinically significant anxiety on the test anxiety scale. In addition, the results indicate a slight elevation of anxiety on the scale of restlessness, physiological anxiety, social concern, and total anxiety.

Table 1

Results of the State-Trait Anxiety Questionnaire

\begin{tabular}{lcc}
\hline Type of Anxiety & Score & Level \\
\hline Anxiety - Trait & 46 & High \\
Anxiety - State & 32 & Medium \\
\hline
\end{tabular}

Table 2

Results of the Hamilton Anxiety Scale

\begin{tabular}{lc}
\hline Dimension & Score \\
\hline Psychic Anxiety & 12 \\
Somatic Anxiety & 7 \\
\hline
\end{tabular}

Table 3

Results of the Manifest Anxiety Scale in Adults - $C$, format for university students

\begin{tabular}{lcc}
\hline Scale & T Score & Description \\
\hline $\begin{array}{l}\text { Restlessness/ } \\
\text { Hypersensitivity }\end{array}$ & 66 & $\begin{array}{c}\text { Slight } \\
\text { elevation }\end{array}$ \\
Physiological anxiety & 53 & $\begin{array}{c}\text { Slight } \\
\text { elevation }\end{array}$ \\
Test anxiety & 65 & $\begin{array}{c}\text { Clinically } \\
\text { significant }\end{array}$ \\
Social concern/ stress & 58 & $\begin{array}{c}\text { Slight } \\
\text { elevation }\end{array}$ \\
Total Anxiety & 63 & $\begin{array}{c}\text { Slight } \\
\text { elevation }\end{array}$ \\
Lie & & $\begin{array}{c}\text { Questionable } \\
\text { (possible } \\
\text { exaggeration } \\
\text { of symptoms) }\end{array}$ \\
\hline
\end{tabular}

On the other hand, in the Beck-II Depression Inventory, her results were classified as mild depression (see Table 4). In contrast, in the Hamilton Depression Assessment Scale, his results show that she presents severe depression (Table 5). 
Table 4

Results of the Beck-II Depression Inventory

\begin{tabular}{cc}
\hline Score & Level \\
\hline 16 & Mild Depression \\
\hline
\end{tabular}

Table 5

Results of the Hamilton Depression Rating Scale

\begin{tabular}{cc}
\hline Score & Level \\
\hline 21 & Severe Depression \\
\hline
\end{tabular}

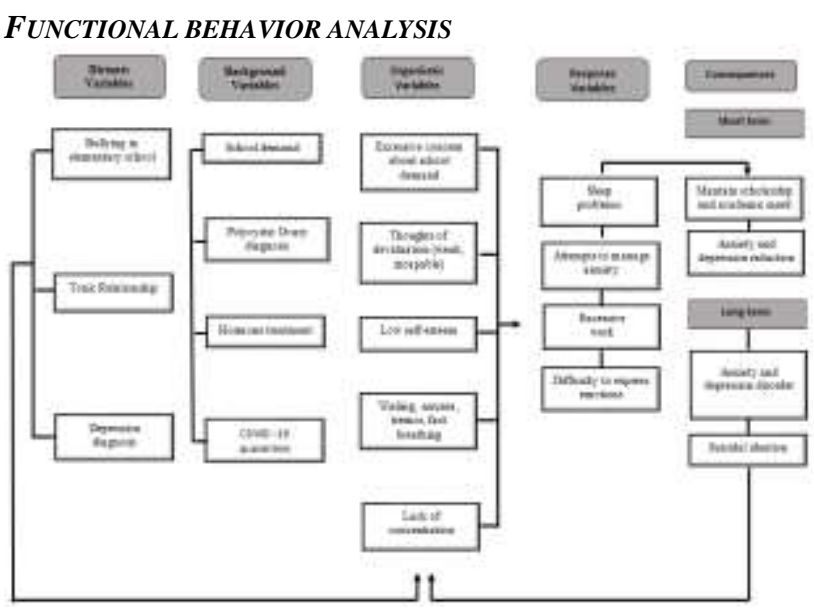

Figure 1. Clinical Map of Pathogenesis

Own elaboration

\section{STUDY OF THERAPEUTIC OBJECTIVES AND TREATMENT GOAL}

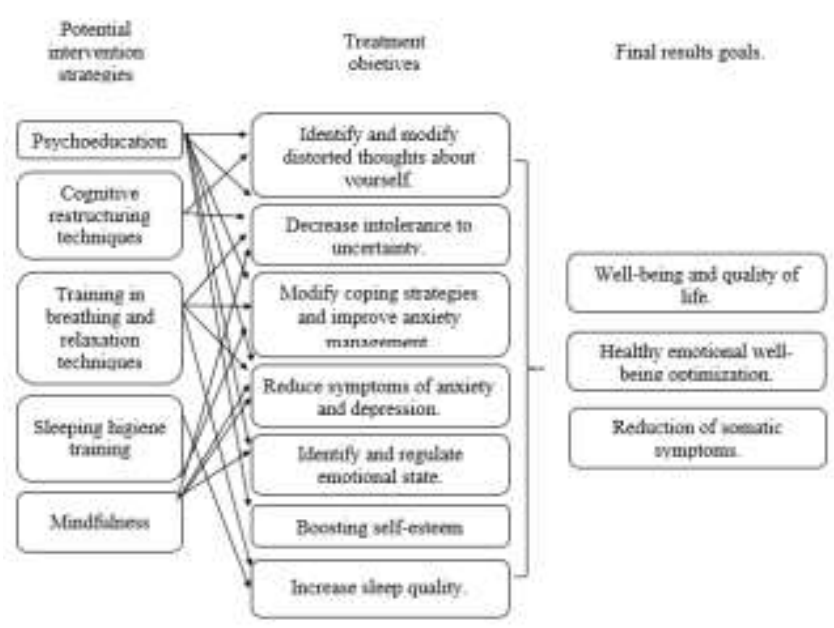

Figure 2. Goals cope map

Own elaboration

\section{SELECTION OF THE MOST VIABLE TREATMENTS.}

The techniques presented below were chosen based on the results of the applied tests, the clinical map of pathogenesis, the expected goals of the therapeutic process, and the bibliographic review. All these strategies must be adapted for online work, generating material for clinical use that can be used remotely as audiovisual material, Apps, and the generation of tools using technology.

\section{Psychoeducation}

Psychoeducation is a key tool in the therapeutic process for the patient and their families. This technique allows a mental health professional to provide detailed and concrete current scientific information that can answer questions related to the origin, evolution and possible outcomes; Furthermore, it allows a better approach to the condition (Albarrán \& Macías, 2007; as cited in Cuevas \& Moreno, 2017).

\section{Cognitive restructuring technique}

Cognitive variables related to depression disorder are categorized into three levels: negative automatic thoughts ("I'm useless"), distorted or nonadaptive assumptions ("If I ask for a promotion they will laugh at me because I'm a fool"), and dysfunctional self-schemas ("I am not good for relating to other people") (Nezu, Nezu \& Lombardo, 2006). This technique uses intervention strategies that allow the reduction of the user's dysfunctional cognitive factors. These strategies are based on cognitive restructuring principles. On the other hand, there are specific strategies such as emotional-rational, cognitive therapy, and self-instructional training. It must be said that the three present different approaches but share the same purpose: to help the patient to identify his maladaptive thoughts better to be able to alter them (Beck et al., 1979, Ellis, 1994; Meichenbaum, 1977; as cited in Nezu et al., 2006). Concerning anxiety, various authors (Beck, Enery, \& Greenberg, 1985; as cited in Nezu et al., 2006), focus their strategies on helping the patient to identify dysfunctional thoughts (such as cognitive distortions of the catastrophic type, generalizations, divinations, diatomical thoughts, etc.). Once these basic ideas have been determined, the patient is instructed to eliminate them and replace them with more functional ideas ("I can't do anything right" vs. "it may be difficult, but I can do it") (Nezu et al., 2006).

3. Training in breathing techniques

Usually, anxiety is accompanied by accelerated and unconscious breathing, causing a decrease in carbon dioxide in the blood, resulting in stun and dizziness experiences, generating even more harmful symptoms for the person.

\section{Training in relaxation techniques}

Patients with anxiety disorder have difficulty achieving relaxation. Relaxation training provides various types of relaxation for patients to reduce anxiety-related somatic symptoms; some of the techniques that these training addresses are the following: progressive muscle relaxation, diaphragmatic breathing, guided positive imagery, meditation, biofeedback, etc. It is worth mentioning that various studies (Öst, Breitholtz, 2000; as cited in Nezu et al., 2006) affirm that this training is effective for anxiety symptoms.

\section{Sleep hygiene training}

This technique helps the patient with anxiety establish sleep behaviors that provide rest (Leahy \& Holland, 2000; as cited in Nezu et al., 2006). In this training, the patient develops a regular sleep program (going to bed and getting up daily at the same time, without exception). Intending to establish a conditioned correspondence between his physical space (his bed) and their sleep habits. To practice some rules on the use of the area, which may be that the bed is only used for sleep and having sex and not for reading, watching television, browsing the cell phone, etc. (Nezu, et al., 2006). 
6. Mindfulness techniques

Vallejo (2006; as cited in Ruiz, Díaz \& Villalobos, 2012) defines mindfulness as: "[...] full awareness, attentive and reflective presence. At the particular moment, terms such as attention, awareness, and reference are fully included in its meaning. Therefore, it proposes an effort to focus on the present moment, in an active and reflective way [...]" (p.474). This technique allows the patient with anxiety to contact her environment, avoiding thoughts directed to the future. It helps her be more conscious about the physical symptoms that might experiment because of anxiety and depression.

Due to excessive worry about the future, the mindfulness technique is recommended in patients with anxiety. The goal is to educate the patient so that she can accept the present and avoid worrying about what might happen in the future. This technique is usually carried out in conjunction with psychoeducation, relaxation, and exposure techniques, among others (Roemer \& Orsillo, 2002; as cited in Nezu et al., 2006).

Given that the therapeutic process was prepared to be carried out in online mode, the application of these techniques will be modifiable depending on the skills and tools available. Arguero and collaborators (2020) explain some of the considerations for the OnLine therapeutic process:

1. Have knowledge and skills about the proper use and management of different technologies.

2. Develop the degree of empathy needed to provide the care the patient requires in emergencies through phone calls.

3. The therapist must know every tool he might count with, as well, those with which he/her can have access.

4. Consider the quality of the connection, such as the telephone network and the internet, and the contextual conditions where the therapist and the patient are located.

5. Reserve a suitable place to provide psychotherapeutic care, avoid noise and external distractions, and create an environment of trust and confidentiality.

6. Take care of the safety of the psychological tests and the therapeutic material to be used during the process. Use standardized instruments in the patient's population and carefully follow the instructions in the application manual.

\section{CONCLUSIONS}

The psychologist must carry out a thorough preparation of his intervention proposal, integrating the information obtained through the interview, the behavioral, functional analysis, and the psychometric tests. Behavioral Functional Analysis serves as a fundamental tool that allows identifying specif behavior problems that need to be corrected and any factor that maintains those conducts. Similarly, the clinical case formulation by Nezu, Nezu, and Lombardo (2006) allows a pictographic representation of the variables involved in the presence of specific symptoms. Furthermore, it also functions to establish which battery of assessment instruments should be applied according to the case.
In relation to what was established by Keawe, Godoy, O Brien, Haynesa and Gavino (2013); Ramirez (2015), and Cooper and Heron (2019), a case study allows us a better understanding that makes it possible to develop an adequate psychological treatment for any patient, because of the collection data process that they present that make it easy to identify several effective techniques that have been applied on other patients who share similarities (such as origin and triggering factors, psychobiological responses, etc.) regarding the behavioral problem; at the same time, study cases helps understanding why any factor that is involved in the patient's conduct, manifest themselves under specific circumstances. On the other hand, based on the study made by Soto and Escribano (2019), we also agree that it is vital not to generalize the idea of what was functional to one patient will work efficiently in others.

Regarding the decision of developing an intervention proposal based on the cognitive-behavioral therapy directed to the selected patient -who presents anxiety and depression traits-, it was based on the several studies made by Olthuis et al. (2015) and Gaja (2017). They mentioned that this therapy is one of the best alternatives, either in online or face-to-face modality. In the same way, Knaevelsrud and Maercker (2007) and Flores et al. (2014) use this kind of psychological intervention with patients with depression.

It is relevant to highlight the importance of online therapeutic support, owing to the COVID-19 contingency, that is due to the most recent clinical attention experiences to provide mental health services to those who suffer from anxiety and depression symptoms. This is important because of the increasing demand for clinical care. That is why is essential that mental health professionals be trained in the use of therapeutic technology tools, psychological first aid, and cognitive-behavioral techniques.

We recommend developing new studies that analyze the efficacy of online cognitive-behavioral therapy to find out its involvement in the design and therapeutic proposal.

Finally, we believe that this article contributes towards the new normality and expands the general knowledge and preparation that we need for future challenges related to how to face new problems in psychological care. So we must remember that a proper case formulation is the stone cornerstone of success in psychological intervention.

\section{REFERENCES}

Argüero, A., Cervantes, B. S., Martínez, J., Alva, N. T., de Santos, F., Espinosa, I. M., Parra, E. L., Aguirre, D. P., Gómez, J., Díaz, D. P., Beltrán, I. L., \& Bautista, R. M. (2020). Guía de atención psicológica virtual para personas de grupos vulnerables en crisis por la pandemia Covid-19. Universidad Autónoma de Nayarit. https://bit.ly/3bip6FW

Benke, C., Autenrieth, L. K., Asselmann, E., \& Pané-Farré, C. A. (2020). Lockdown, quarantine measures, and social distancing: Associations with depression, anxiety and distress at the beginning of the COVID-19 pandemic among adults from Germany. Psychiatry Research (293), 113462. doi:10.1016/j.psychres.2020.113462

Castro, I. M. (2016). Propiedades psicométricas del inventario de ansiedad: rasgo-estado (IDARE) [Tesis de Doctorado, Universidad César Vallejo]. Repositorio Universidad César Vallejo. 
Consejo Mexicano de Neurociencia A.C. (10 de Octubre de 2018). Salud mental y atención psiquiátrica en México. Consejo Mexicano de Neurociencias A. C. https://www.consejomexicanodeneurociencias.org/post/ salud-mental-y-atenci\%C3\%B3n-psiqui\%C3\%A1tricaenm\%C3\%A9xico

Cooper, J. O., Heron, T. E., \& Heward, W. L. (2019). Applied Behavior Analysis (3rd Edition). Hoboken, NJ: Pearson Education.

Cuevas, J.J., \& Moreno, N.E. (2017). Psicoeducación: intervención de enfermería para el cuidado de la familia en su rol de cuidadora. Enfermería Universitaria 14(3), 207218. https://doi.org/10.1016/j.reu.2017.06.003

De la Rosa, A., Moreyra, L. \& De la Rosa, N. (2020). Intervenciones eficacies vía Internet para la salud emocional en adolescentes: Una propuesta ante la pandemia por COVID-19. Hamut'ay, 7 (2), p. 18-33. http://dx.doi.org/10.21503/

Espinosa, M.C., Orozco, L.A., \& Ybarra, J.L. (2015). Síntomas de ansiedad, depresión y factores psicosociales en hombres que solicitan atención de salud en el primer nivel. Salud Mental, 38(3), 201-208 http://dx.doi.org/10.17711/SM.0185-3325.2015.028

Esquivel, P. (2013). Funcionalidad familiar y su asociación con estrés, ansiedad, depresión en pacientes con diabetes mellitus tipo 2 de la Unidad de Medicina Familiar No. 75, 2012. [Tesis de Licenciatura, Universidad Autónoma del Estado de México]. http://ri.uaemex.mx/handle/20.500.11799/14014

Estrada, B.D., Delgado, C., Hernández, R., \& González, M.T. (2015). Propiedades psicométricas del modelo bifactorial del BDI-II (versión española) en muestras mexicanas de población general y estudiantes universitarios. Universitas Psychologica, 14(1), 125136. http://dx.doi.org/10.11144/ Javeriana.upsy141.ppmb

Fernández-Aranda, F., Casas, M., Claes, L., Bryan, D.C., Favaro, A., Granero, R., Gudiol, C., Jiménez-Murcia, S., Karwautz, A., Le Grange, D., Menchón, J.M., Tchanturia, K., \& Treasure, J. (2020), COVID-19 and implications for eating disorders. Eur Eat Disorders Rev, 28 ,239-245. https://doi.org/10.1002/erv.2738

Flores, L.A. Cárdenas, G., Durán, X., \& De la Rosa, A. (2014). Psicoterapia vía internet: aplicación de un programa de intervención cognitivo-conductual para pacientes con depresión. Psicología Iberoamericana, 22(1), 7-15.

Gaja, M. (13 de mayo de 2017). La terapia cognitivo conductual es más eficaz que los fármacos para tratar la ansiedad y depresión. Instituto Superior de Estudios Psicológicos. https://bit.ly/33APRRu

Instituto Nacional de Estadística y Geografía. (2019). Estadísticas a propósito del día mundial para la prevención del suicidio. [Archivo PDF]. https://www.inegi.org.mx/contenidos/saladeprensa/aprop osi to/2019/suicidios2019_Nal.pdf

Kazdin, A. E. (2019). Single-case experimental designs. Evaluating interventions in research and clinical practice. Behav Res Ther. 117, 3-17. doi: 10.1016/j.brat.2018.11.015
Keawe, J., Godoy, A., O Brien, W., Haynesa, S., \& Gavino, A. (2013). Análisis funcional en evaluación conductual y formulación de casos clínicos. Ciencia y Salud, 24(2), 117-127. http://dx.doi.org/10.5093/cl2013a13

Knaevelsrud, C., \& Maercker, A. (2007). Internet-based treatment for PTSD reduces distress and facilitates the development of a strong therapeutic alliance: A randomized controlled clinical trial. BMC Psychiatry 7, 13. https://doi.org/10.1186/1471-244X-7-13

Li S., Wang Y., Xue J., Zhao, N., \& Zhu, T. (2020) The Impact of COVID-19 Epidemic Declaration on Psychological Consequences: A Study on Active Weibo Users. International Journal of Environmental Research and Public Health. $17 \quad$ (6):2032. https://doi.org/10.3390/ijerph17062032

Navarrete-Garduño, J.C. (2014). Frecuencia de depresión en pacientes diabéticos e hipertensos en el centro de salud rural disperso Portezuelos Jiquipilco México de agosto 2013 a junio del 2014. [Tesis de titulación, Universidad Autónoma del Estado de México]. https://core.ac.uk/download/pdf/55520107.pdf

Nezu, A., Nezu, C., \& Lombardo, E. (2006). Formulación de casos y diseño de tratamientos cognitivo conductuales: Un enfoque basado en problemas. Manual Moderno.

Olthuis, J. V., Watt, M.C., Bailey, K., Hayden, J.A., \& Stewart, S. (2015). Terapia cognitivo-conductual por Internet asistida por un terapeuta para los trastornos de ansiedad en adultos. Cochrane Library. https://doi.org/10.1002/14651858.CD011565

Ramírez, M. (2015). Tratamiento cognitivo-conductual de conductas disruptivas en un niño con TDAH y trastorno negativista desafiante. Revista de Psicología Clínica con Niños y Adolescentes, 2(1), 45-54

Reynolds, C., Richmond, B. \& Lowe, P. (2007).: Escala de Ansiedad Manifiesta en Adultos: AMAS. El Manual Moderno.

Ruiz, M. A., Díaz, M. I., \& Villalobos, A. (2012). Manual de Técnicas de Intervención Cognitivo Conductuales. Desclee de Brouwer.

Soto, E., \& Escribano, E. (2019). El método de estudio de caso y su significado en la investigación educativa. En Arzola, D. M. (coord.), Procesos formativos en la investigación educativa. Diálogos, reflexiones, convergenciasy divergencias (pp. 203-221). Chihuahua, México:Red de Investigadores Educativos Chihuahua.

Vindergaard, N., \& Eriksen, M. (2020). COVID-19 pandemic and mental health consequences: Systematic review of the current evidence. Brain, behavior, and immunity (89) p. 531-542 https://www.sciencedirect.com/science/article/pii/S0889 159120309545?via\%3Dihub

Wagner, B., Horn, A., \& Maercker, A. (2014). Internet based versus face-to-face cognitive-behavioral intervention for depression: A randomized controlled non-inferiority trial. Journal of Affective Disorders (152-154), p. 113121 
https://www.sciencedirect.com/science/article/abs/pii/S 0165032713005120 ?via\%3Dihub

Zhang, W. R., Wang, K., Yin, L., Zhao, W. F., Xue, Q., Peng, M., Min B., Tian Q., Leng H., Du J., Chang H., Yang Y., Li W., Shangguan F., Yan T., Dong H., Han Y., Wang Y., Cosci F., \& Wang, H.X. (2020). Mental health and psychosocial problems of medical health workers during the COVID-19 epidemic in China. Psychotherapy and psychosomatics, 89(4), 242-250. 